\title{
SILVER ECONOMY IN RURAL DEVELOPMENT STRATEGIES
}

\author{
Grażyna Krzyminiewska ${ }^{\bowtie}$ \\ Poznań University of Economics and Business, Poland
}

\begin{abstract}
This paper deals with the issue of silver economy assumptions which, when implemented, will enable converting demographic problems into specific development opportunities. It presents the use of the silver economy paradigm in creating the rural development strategy. This paper assumes that a development strategy which addresses the needs of the ageing population fosters an improvement in living standards not only for the elderly but also for other members of the population. In the case of rural areas and agriculture, it preserves the multi-functionality of rural areas and helps the local inhabitants continue exercising their various professions. The content of this paper is in line with economic and social analyses underpinned by achievements in sociological and economic research, and is based on existing sources and outcomes of own research. A descriptive analysis was used to present the issues considered.
\end{abstract}

Keywords: silver economy, rural areas

\section{INTRODUCTION}

The analysis of demographic trends explicitly indicates that the world's population is ageing at unprecedented rates. It is assumed that population ageing means an increase in the percentage of the elderly with a simultaneous decline in the percentage of children. The literature usually sets the old-age threshold at 60 (WHO) or 65 (UN, Eurostat). There are many measures and classifications of the population ageing process. In accordance with the UN criterion, a population with at least $7 \%$ of people aged 65 or more is considered to be an aging society (or, if the percentage exceeds $10 \%$, an aged society). As forecasted by the Central Statistical Office (GUS), in 2050, the share of people aged 65 or more in the total population will be $30.2 \%$, whereas people aged 80 or more will account for $10.4 \%$ of the total population (vs. 3.9\% in 2013) (GUS, 2014).

Undoubtedly, these figures are a reason to analyze and broadly discuss the phenomenon, and to develop effective strategies addressing its aspects and implications. In many cases, focus is placed on adverse effects of ageing (which is understandable in all respects), triggered by the concern that the demographic burden would have a negative impact on the development capacity of a given society (including in Poland). Particular emphasis is placed on factors which include inefficient care systems and social security systems. On the other hand, an opposite approach to population ageing has emerged, focusing on new development opportunities consistent with the silver economy concept. Silver economy means an economic system oriented towards adjusting the manufacturing and distribution of goods and services to the needs of the ageing population. In accordance with this concept, silver economy may represent a new development paradigm for ageing Europe while also providing a development opportunity for Poland (Niewiadomska and Sobolewska-Poniedziałek, 2015).

\section{SILVER ECONOMY AS A DEVELOPMENT OPPORTUNITY}

The silver economy concept perfectly fits the idea of social development based on the belief that economic growth must be linked to social progress in all spheres

\footnotetext{
Prof. PhD hab. Grażyna Krzyminiewska, Department of Sociology and Economic Ethics, Poznań University of Economics and Business, Al. Niepodległości 10 St., 61-875 Poznań, Poland, e-mail: grazyna.krzyminiewska@ue.poznan.pl; https://orcid. org/0000-0002-1573-3771
} 
of life, so that people could be more and more responsible for their welfare and social security. ${ }^{1}$ The idea of human development refers directly and indirectly to those threads in social thought which define development and social progress mainly as a process of improvements in human life quality and which consider economic growth to be a measure in meeting this goal rather than "a goal in itself" (Księżopolski, 1995).

The reason for the above is that the economy of ageing societies is both a challenge and a development opportunity. On the one hand, the nature of silver economy can be beneficial for the economy as a whole whereas on the other hand, it may provide care for, and address the needs of, the elderly. According to researchers, Japan pioneered an economic system designed to address the needs of the elderly in the 1970s. As a response to a significant share of old people in the society, Japan developed (and used the outcomes of) gerontology; these measures are believed to be at the core of the silver economy concept (Klimczuk, 2011).

An outline of the European silver economy concept appeared in European Union documents drawing attention to the fact that the "ageing population can even represent a good opportunity to enhance the competitiveness of the European economy" through the production of "goods and services which respond to the needs of an older clientele" (Commission of the European Communities, 2006). In addition, as highlighted in subsequent documents, the development of innovative enterprises will also enable expanding the development capacity based on global markets since the ageing problem is becoming characteristic for many non-European countries. Thus, the opportunity appears to export the developed solutions, products and services to other countries (Commission of the European Communities, 2009).

In the Polish literature on the subject, Golinowska (2014) uses a very accurate definition of silver economy.

1 "The basic purpose of development is to enlarge people's choices. In principle, these choices can be infinite and can change over time. People often value achievements that do not show up at all, or not immediately, in income or growth figures: greater access to knowledge, better nutrition and health services, more secure livelihoods, security against crime and physical violence, satisfying leisure hours, political and cultural freedoms and sense of participation in community activities. The objective of development is to create an enabling environment for people to enjoy long, healthy and creative lives." UNDP, http://hdr.undp.org/en/ humandev/.
Accordingly, silver economy involves matching supply to the changing needs of various groups of the elderly, so they may stimulate economic activation. Regardless of the approach to defining silver economy, it always involves economic operators undertaking supply activities targeted at the elderly who become beneficiaries of this process. As Szukalski (2012) emphasizes, the economy can be at various development stages of silver economy (Table 1).

The essence of silver economy is not only the positive impact on the quality of life in elderly people. It also has a positive effect on the labor market, resulting in friendly relationships with older employees and a better understanding of the needs and problems of the elderly. Also, it gives momentum to the creative sector and stimulates employment growth in hi-tech sectors (a domain of the young generation). The classification by Enste et al. (2008) includes the following industries identified as those where silver economy may stimulate the development of market sectors either directly or indirectly related to population ageing:

- information technology (IT) in healthcare

- adapting dwellings and life-facilitating services based primarily on IT

- independent living based on the growing adoption of IT

- areas of gerontology significant for health economics, including medical technologies, e-health, visual and hearing support, prosthetics and orthopedics

- education and culture as a response to the people's willingness to develop and manage their free time

- IT and media which are related to medicine and promote independence and security

- robotics underpinning the services related to the promotion of independent living for elderly people suffering from severe diseases

- mobility and promotion of its components, e.g. traffic safety

- leisure, travel, culture, communication and entertainment

- fitness and wellness as a way to trigger the awareness of healthy lifestyles

- clothing and fashion as a symptom of seeking social integration

- services helping in day-to-day life and household works

- insurance which mainly covers risk forms typical of the elderly 
Table 1. Development stages of silver economy

\begin{tabular}{|c|c|c|}
\hline Stages & Characteristics & Target group \\
\hline Stage 1 & $\begin{array}{l}\text { 1. Modifying the existing products to make them more useful to the elderly } \\
\text { 2. Implementing products dedicated to the elderly, addressing their needs arising from the } \\
\text { ageing process }\end{array}$ & Elderly \\
\hline \multirow[t]{3}{*}{ Stage 2} & $\begin{array}{l}\text { 1. Ensuring a maximum of independent living } \\
\text { - services enabling a longer stay at home (cleaning, shopping, care), } \\
\text { - making the population aware of the existence and ways of using some technological } \\
\text { solutions designed to compensate for the disability } \\
\text { - organization of transport services } \\
\text { - activity of companies offering smart home solutions (premises with a system of equip- } \\
\text { ment helping to live an independent life); } \\
\text { 2. Time management for the elderly } \\
\text { - education, entertainment, tourism and leisure } \\
\text { - services for pets } \\
\text { 3. "Age-sensitive" financial services }\end{array}$ & Elderly \\
\hline & $\begin{array}{l}\text { 4. Providing social integration } \\
\text { - Activities focused on achieving an enhanced sense of community between various } \\
\text { social groups, including representatives of different generations }\end{array}$ & $\begin{array}{l}\text { Groups and organizations } \\
\text { in contact with old people }\end{array}$ \\
\hline & $\begin{array}{l}\text { 5. Products and services in support of economic activity } \\
\text { - providing individuals with updated qualifications, skills and knowledge so they may } \\
\text { successfully continue their professional career; } \\
\text { - providing organizations with knowledge and skills on how to adapt workplace condi- } \\
\text { tions and work organization to the requirements of ageing labor resources }\end{array}$ & Young-old \\
\hline
\end{tabular}

Source: Szukalski, 2012.

- financial services, in particular capital protection, wealth preservation and prevention against the loss of savings.

It can be seen that the industries listed above are fully covered under stage 2 of silver economy development.

\section{SILVER ECONOMY IN RURAL AREAS}

The development of silver economy in rural areas has two important aspects. Firstly, problems of old people have been so far addressed by their families, which is an obvious and desirable behavior. However, it becomes difficult in the contemporary world. The key issue is the shift from the extended family model (characteristic of rural areas until recently) to a smaller family, together with a change in its demographic structure. This is associated with:

- higher employment rates of women (including outside agriculture) who used to be caretakers
- young generation migrating to larger towns (searching for education and jobs or guided by the expected improvements in the standards and quality of living)

- economic emigration of younger generations, resulting in the "euro-orphanhood" of children (and currently also of the elderly).

Secondly, rural areas face increasing difficulties in accessing care services and social infrastructure which would help the elderly in living their lives. The current state of affairs is not satisfactory, and the development of silver economy provides an opportunity to reduce inequalities in access to care and other services, to expand the multifunctional development model for rural areas as well as to enhance the economic development, in broad terms. As shown by the analysis of principal assumptions of silver economy, the key concept is to implement dedicated solutions to enable the transformation of demographic problems into specific development opportunities. 


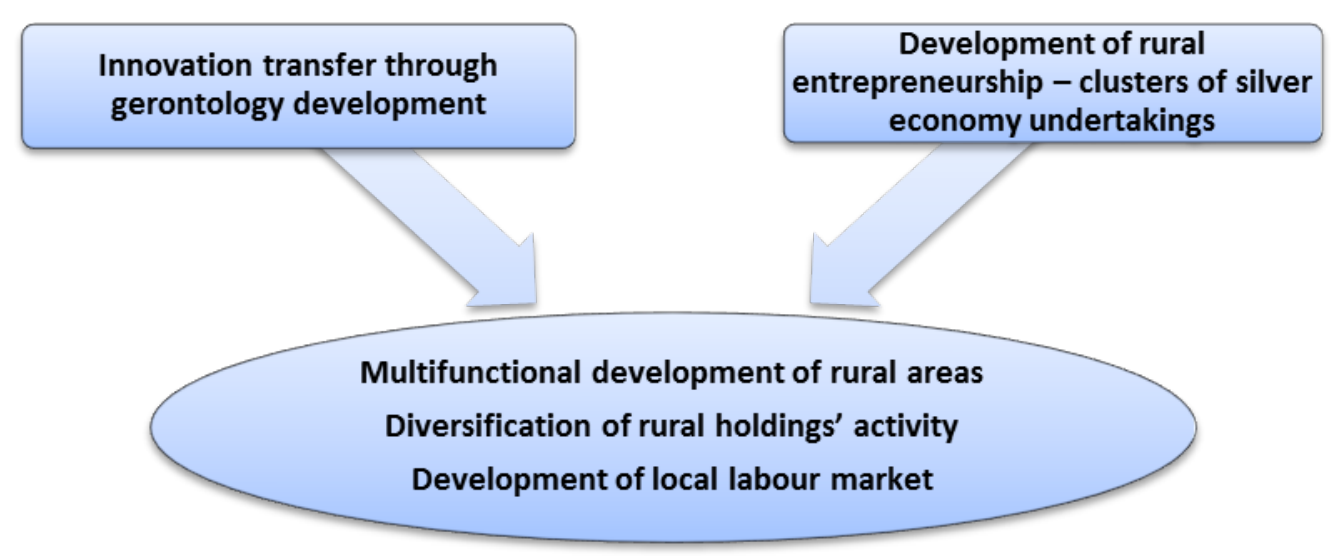

Fig. 1. Impact of a senior-oriented economy on the development of rural areas Source: own elaboration.

In rural areas, silver economy can evolve around many aspects of management. Figure 1 indicates the positive direct effects of specific elements of a seniororiented economy on the development of rural areas.

\section{MAJOR DEVELOPMENT OPPORTUNITIES FOR SILVER ECONOMY IN RURAL AREAS}

Both for rural areas and for cities, undergoing the same ageing processes, silver economy becomes an opportunity (and also a challenge) to implement economic solutions that harness this process in order to stimulate the market and boost local entrepreneurship. Rural areas offer specific values which, to a certain extent, are determinant for their competitive advantage, and can be tapped into by economic (and social) undertakings such as: - care farms

- rural tourism for seniors

- rural "silver sector" undertakings

- development of social entities.

The task of care farms, also referred to as "social agriculture," is to link daycare or long-term care services with elements of agricultural production and breeding. A care farm is defined as a form of support in the area of care and social integration provided by a holding engaged in agricultural activity (Care farms..., 2017). Services provided by those farms are also offered to the seniors (and to the disabled, including intellectually impaired, or other people in need of care and support). In many countries, care farms are incorporated into a broader perspective of agricultural operations, thus creating opportunities for therapeutic activities. In the literature on the subject (Hassink and van Dijk, 2006), this type of activity is referred to as "green care" which also fulfils a therapeutic function on top of strictly defined care functions. Care farms are an opportunity for the implementation of the multifunctional agriculture concept.

For the elderly, care farms may become very attractive as it allows them to socialize while staying in a rural environment, in contact with nature, and having the opportunity to actively participate in the life of an agricultural holding. It is unquestionably an interesting offer for all those who consider rural living a value in itself. For the elderly originating from rural areas, staying in an environment their are used to may determine the quality of their life.

Benefits stemming from the development of social agriculture are significant for farmers themselves. This is because they acquire a new source of income and, consequently, are able to improve both the standing of their own agricultural holdings and the standards of living for their families. Undoubtedly, this is also an opportunity for professional activation of farm members, in particular women who participated in the open labor market for many years. By engaging in the organization and running of a care farm, they gain the opportunity to acquire income.

At present, to run a care farm, the operator is required to establish a social economy entity or an economic activity entity in the form of a day center, family-run accommodation and a 24-hour care facility. 
On the other hand, tourism for the elderly is an activity about to develop rapidly in the coming years. It mainly results from the increasing wealth of the society and from a major change of mindset in the social environment of the elderly (and from changes in behavior of old people themselves). Nowadays, ageing is perceived as a certain stage of life which does not necessarily mean giving up any activity and staying at home all the time. Modern seniors are open to new experiences and challenges; this is especially true for the young-old population who still have plenty of vitality. Therefore, the consumers expect interesting offers, including in the area of tourism.

Rural tourism for the elderly has excellent development opportunities and may constitute another area of economic activity for the rural population. It meets with success already now, and the market potential should be fully tapped into. It should be mainly emphasized that seasonal variations in the tourist activity of the elderly are negligible since the seniors are not linked with the labor market.

Nevertheless, as Niezgoda and Jerzyk wrote (2013, p. 478), a relatively large group of elderly visitors requires a special offer. In the future, the elderly will gain importance as a segment of tourism. Therefore-while preparing the supply in tourist destinations - the attitude should be changed and the segment of older tourists should not be regarded as having marginal importance. Indeed, in developed countries, the elderly are not willing to give up their customary activities when traveling; instead, they want to enjoy their time and are ready to pay more for a higher quality of service. Within several or ten to twenty years, people who now are professionally active will become a group of seniors; therefore, their current leisure preferences will turn into preferences of a group of seniors.

It is also essential that rural undertakings strive to adjust their goods and services to the needs of people of various ages, differing in physical fitness and cognitive capacity. This may also enable an improvement in the social integration of their users. Establishing clusters of rural undertakings active in the "silver sector" would unquestionably facilitate their operation on the market. Note also that rural areas continue to be underdeveloped in many aspects, especially including the service sector which faces extensive opportunities for growth. The services include the construction industry which participates in building protected, well-equipped and dedicated dwellings (Rataj et al., 2017). Although poorly developed in Poland, they can be implemented in rural areas. Also, in Poland, there are clusters of services for older people (beside care farms) which extend over a broad spectrum of services such as health, care, education, sports and culture.

Another good solution for rural areas is the development of social entities which, through their activity, may enable social and professional integration and reintegration for people outside the labor market while implementing projects consistent with the silver economy. Non-governmental organizations (foundations and associations), cooperatives, social cooperatives, social integration centers (CIS), professional activity centers (ZAZ) and other institutions deliver measurable benefits for local communities which may therefore rely on own resources in developing their community.

\section{CONCLUSION}

Until recently, ageing societies were viewed only as a highly alarming phenomenon which has even been referred to as the "apocalyptic demography" (Gee and Gutman, 2000). While not ignoring the potential implications of the phenomenon for the social policy, the current point of view puts a stronger focus on possible new development opportunities that may be derived from it. It is emphasized that knowledge economy, technological innovation and entrepreneurship may be helpful in leveraging the power of these demographic trends to create new jobs, professions and management orientations. According to these assumptions, the silver economy paradigm, while creating challenges for the contemporary economy, may become an inherent part of development strategies. New interesting perspectives emerge for rural areas which, if implemented adequately and consistently, should permanently fit in the development trends, enabling sustainable employment in various areas of silver economy. Note that the elderly are not a homogeneous group (and may become even more heterogeneous) which enables the creation of a diversified offering for a diversified community. It is obviously indispensable to create conditions for the development of silver economy, and provide the "silver branch" of the private sector with support from the public sector, local governments and NGOs. 


\section{SOURCE OF FINANCING}

This paper was financed with the resources of the Department of Sociology and Economic Ethics at the Poznań University of Economics and Business.

\section{REFERENCES}

Care farms - building of the cooperation network (2017). In: Social Farming Best Practice Collection in Visegrad Countries (pp. 55-57). Retrieved Oct $10^{\text {th }} 2017$ from: http://socialfarm.gak.hu/sites/default/files/Social_Farms_ in_Visegrad_Countries_web.pd

Commission of the European Communities (2006). The Demographic Future of Europe - from Challenge to Opportunity (COM(2006) 571 final). Brussels: EU COM.

Commission of the European Communities (2009). Dealing with the impact of an ageing population in the EU (2009 Ageing Report)(COM(2009 180 final). Brussels: EU COM.

Enste, P., Naegele, G., Leve, V. (2008). The Discovery and Development of the Silver Market in Germany. In: F. Kohlbacher, C. Herstatt (Eds.), The Silver Market Phenomenon. Business Opportunities in an Era of Demographic Change (pp. 330-331). Heidelberg: Springer.

Gee, E. M., Gutman, G. M. (2000). The Overselling of Population Aging: Apocalyptic Demography, Intergenerational Challenges, and Social Policy. Toronto: Oxford University Press.

Golinowska, S. (2014). Silver economy - an element of regional development strategy. Małop. Stud. Region., 2-3, 31-32.
GUS (2014). Population forecast for 2014-2050. Warszawa: Główny Urząd Statystyczny.

Hassink, J., Hulsink, W., Grin, J. (2014). Farming with care: the evolution of care farming in the Netherlands. NJAS Wagen. J. Life Sci., 68, 1-11.

Hassink, J., van Dijk, M. (Eds.). (2006). Farming for Health: Green-Care Farming Across Europe and the United States of America. Dordrecht: Springer.

Klimczuk, A. (2011). Technology transfer in the development of silver economy. In: M. Grzybowski (Ed.), Knowledge transfer in economics and management (pp. 57-75). Gdynia: Wyd. Uczelniane Akademii Morskiej w Gdyni.

Księżopolski, M. (1995). Pojęcie rozwoju społecznego. Różne koncepcje postępu społecznego i regresu a idea „rozwoju społecznego". Raport o Rozwoju Społecznym [The idea of social development. Various concepts of social progress and decline versus the idea of "social development". Social Development Report). Poland, UNDP, p. 28.

Niewiadomska, A., Sobolewska-Poniedziałek, E. (2015). Silver economy - a new paradigm of development of the ageing Europe. In: Economics of the 21st Century 3 (7) (pp. 65-82). Wrocław: Wyd. Uniwersytetu Ekonomicznego.

Niezgoda, A., Jerzyk, E. (2013). Seniorzy w przyszłości na przykładzie rynku turystycznego [Seniors in the future based on the tourist market example]. Zesz. Nauk. Uniw. Szczec., 777, Probl. Zarz. Fin. Market., 32, 475-489.

Rataj, Z., Iwański, R., Bugajska, B. (2017). Social housing management in Poland in the context of ageing society. European experience and implication for Poland. Ekon.-Man. Spekt., 11(2), 22-31.

Szukalski, P. (2012). Demography and Social Gerontology. Biul. Inf., 7, 1-4. 